\title{
Graduate Student Literature Review: The past and future of soy protein in calf nutrition*
}

\author{
I. Ansia† (1) and J. K. Drackley \\ Department of Animal Sciences, University of Illinois, Urbana 61801
}

\section{ABSTRACT}

Our objective with this review is to encourage more research about the use of soy protein in young calf diets by learning from the mistakes of the past and acknowledging the promising results found when modern techniques are applied to treat soybeans. Total or partial substitution of milk proteins with soy proteins can represent a substantial increase in the economic efficiency of calf diets as long as it does not affect calf performance. Unfortunately, the results found in the literature indicate that the inclusion of soy protein in diets of young calves usually diminishes growth and health outcomes. The interaction of the antinutritional factors and antigenic proteins in soybeans with the gastrointestinal tract triggers a physiological response with negative consequences for the digestive tract and immune system of the calf. In this article, we highlight the importance of a correct processing method of soybeans by reviewing some of the published research that has evaluated different soy-based ingredients in diets for young calves. Conventional methods such as heating, ethanol extraction, and protein isolation can produce favorable results provided that the final product contains minimum or null amounts of antigenic and antinutritional factors. More recently, further processing methods such as microbial treatment of soybean meal reduces those antinutritional and antigenic factors, and can also increase the quality of soy protein by reducing the peptide size and by triggering the release of bioactive compounds. Experiments in which soy protein modified by this method was fed have increased in the scientific literature during the last decade due to the favorable results obtained in calves as well as in monogastric animals.

Received January 29, 2020

Accepted April 4, 2020.

*Submitted to the 2021 ADSA Foundation Graduate Student Literature Review Competition (Production Division, $\mathrm{PhD}$ ) on April 5,2020 .

†Corresponding author: ansiava2@illinois.edu

łAdvisor (drackley@illinois.edu)
Key words: calf, soy protein, antinutritional factors, processing methods

\section{INTRODUCTION}

Milk components are the most expensive ingredients that constitute calf milk replacer (MR) because milk powders are the commodities with the biggest presence within the international dairy trade. Their use has been increasing steadily during the last 2 decades, and, as a consequence, the price of milk powders has also increased (Lagrange et al., 2015). Whey proteins and dried skim milk are among the most common milk powders used for calf MR, and therefore total or partial substitution of milk proteins with lower-cost alternative protein sources can be economically beneficial (Raeth et al., 2016). In the actual economic situation, the price of soy protein is still more competitive than whey protein, and therefore it is one of the most studied alternatives. However, the antinutritional factors (ANF) present in soybeans interfere with the regular gastrointestinal function, negatively affecting growth and normal physiology in young calves (primarily preweaning) as well as in monogastric animals (Lallès, 1993). Since the first attempts at using soy protein as an ingredient for young calves (Shoptaw, 1936), results reported in the literature have shown that direct substitution is generally not satisfactory (Table 1 ).

During the preweaning period, older calves also seem to better resist soybean antigens (Barratt and Porter, 1979) and therefore are able to achieve better performance than younger calves (Akinyele and Harshbarger, 1983). Even though authors attributed this effect to a greater permeability of the mucosal barrier in early stages of development, it is likely that the rapid increase of ruminal microbial and enzymatic activity played a role in the resistance to the antigenic factor in older calves (Rey et al., 2012). In fact, rumen fermentation seems to reduce the appearance of antigenic responses (Tukur et al., 1993). In the weaned calf, no immunological responses to soybean globulins were found, even though trace amounts reached the ileum undigested (Tukur et al., 1993). Fermentation with rumen fluid increases the 
Ansia and Drackley: LITERATURE REVIEW: SOY PROTEIN IN CALF NUTRITION

7626

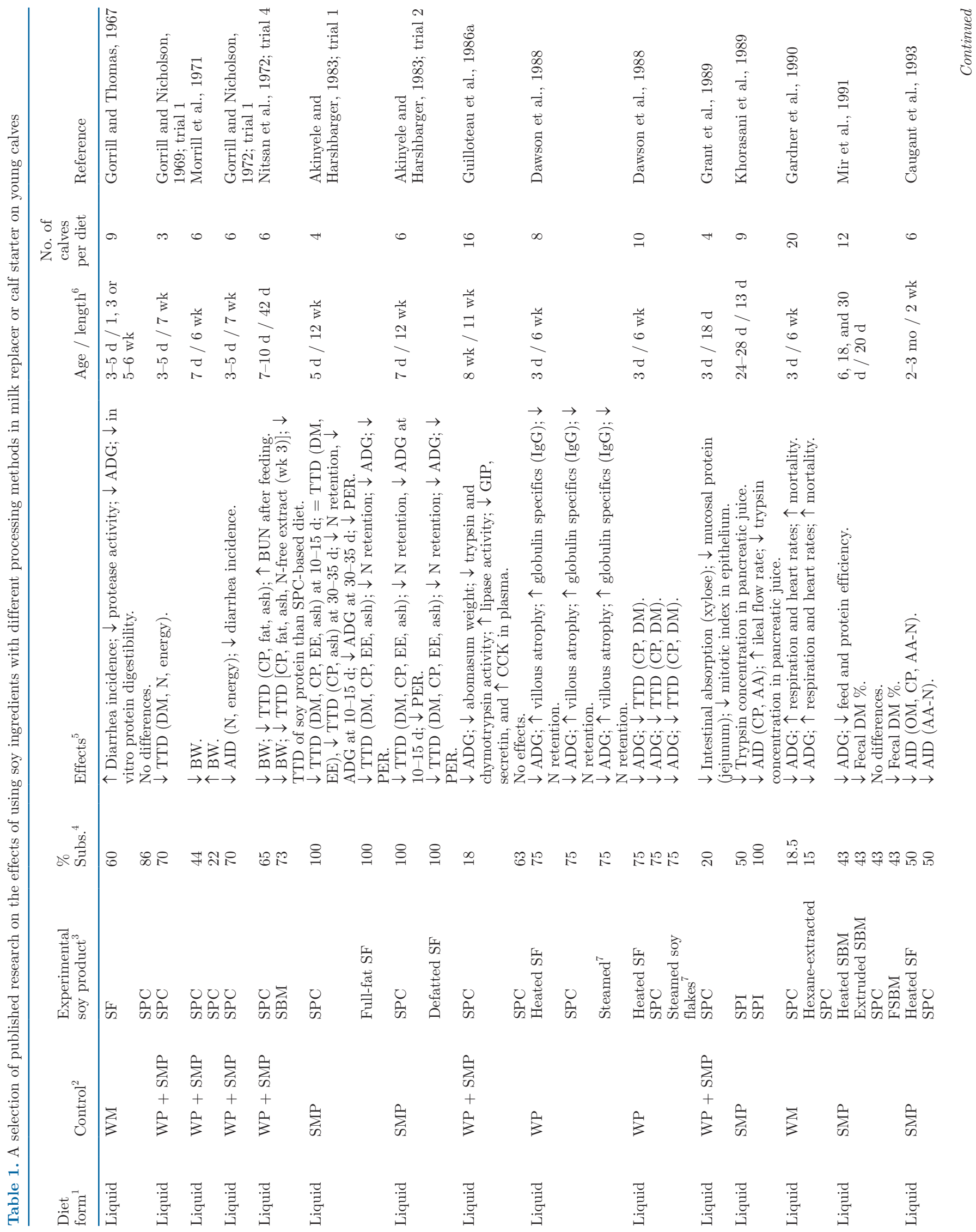

Journal of Dairy Science Vol. 103 No. 8, 2020 
Ansia and Drackley: LITERATURE REVIEW: SOY PROTEIN IN CALF NUTRITION

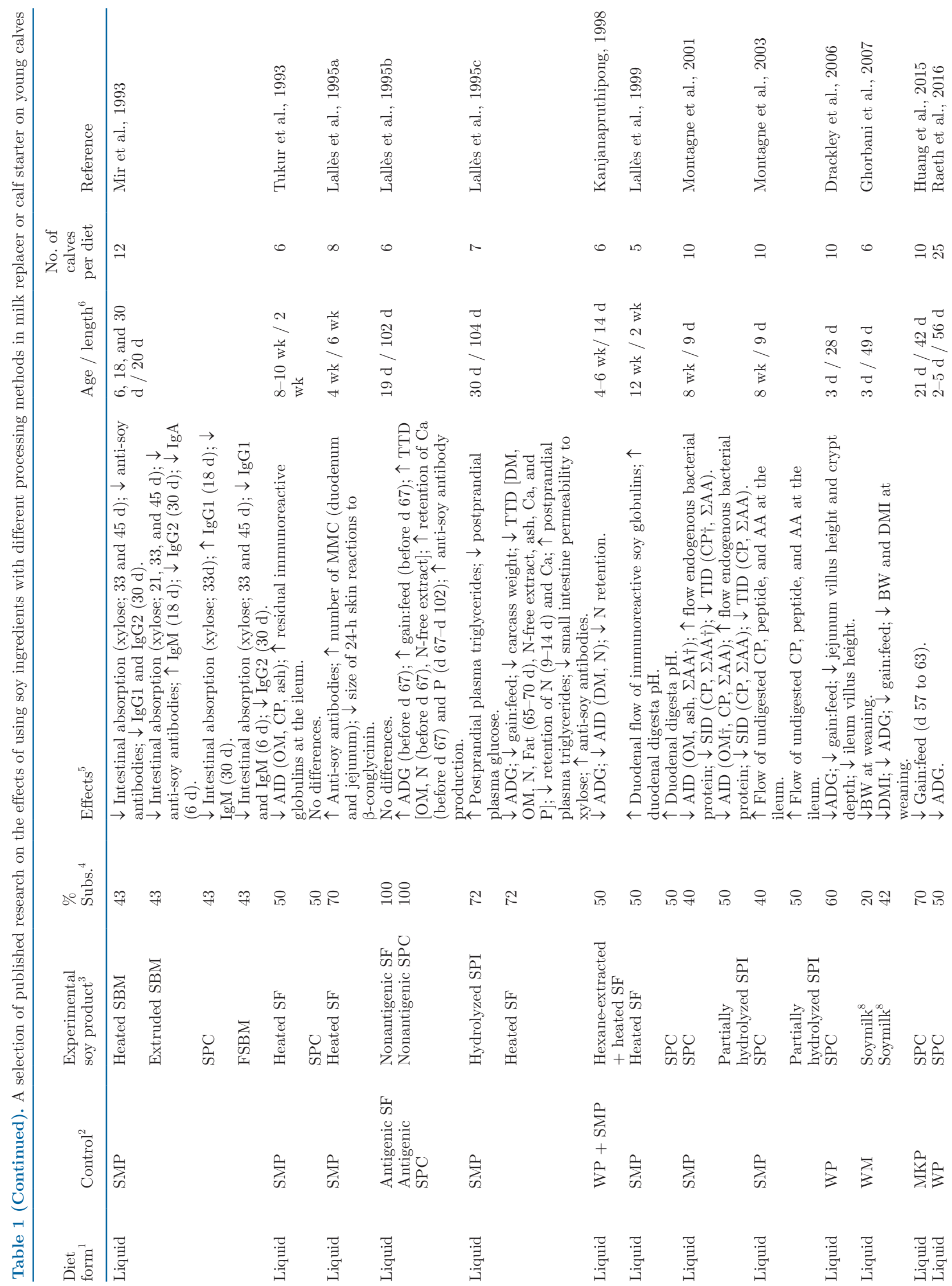


Ansia and Drackley: LITERATURE REVIEW: SOY PROTEIN IN CALF NUTRITION

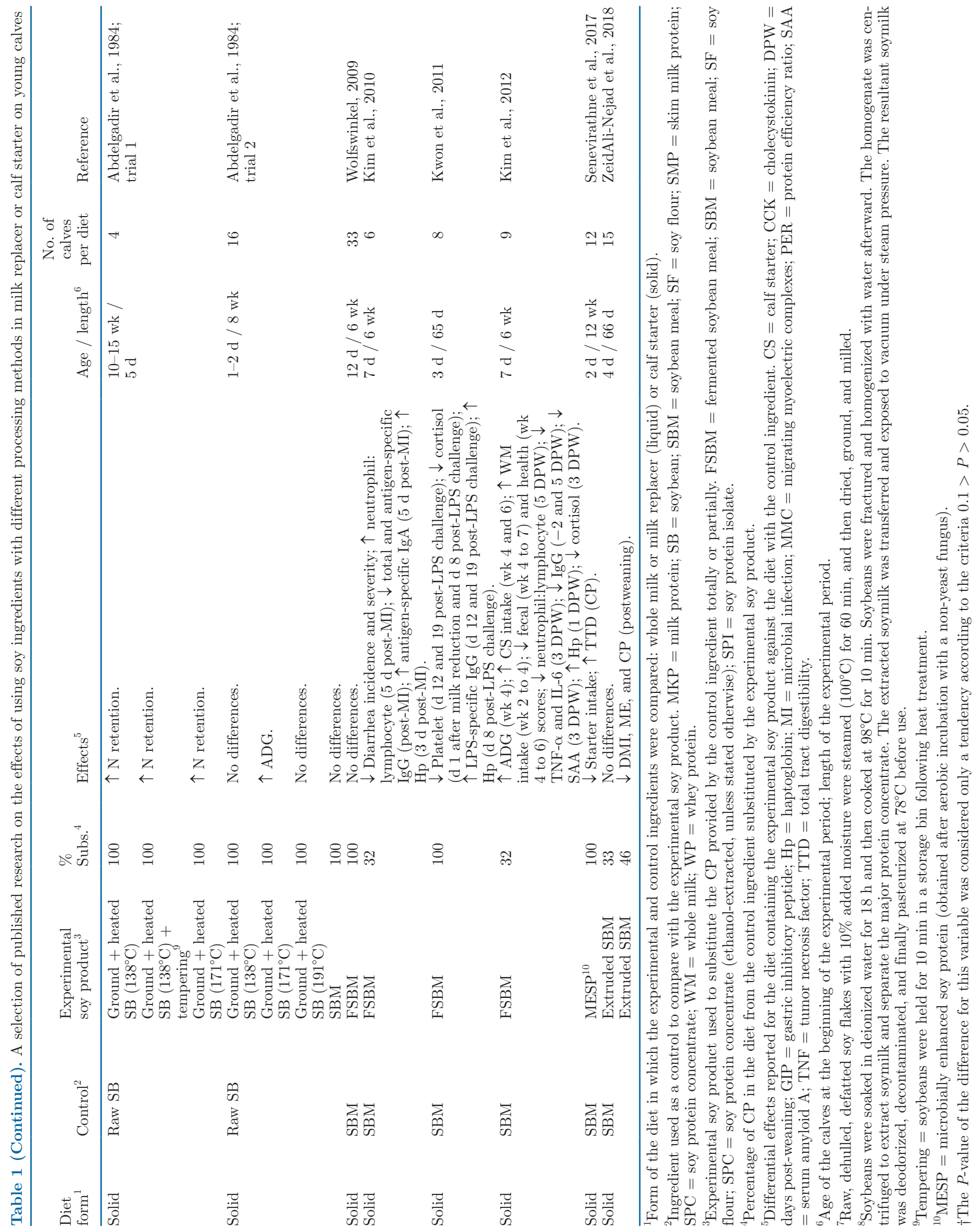


vulnerability of soybean globulins to complete pepsin hydrolysis (Mir et al., 1989), inactivating any possible antigenic capacity (Barratt et al., 1978). Nevertheless, rumen fermentation itself in older calves sometimes does not completely mitigate the negative effects of certain ANF (proteases inhibitors) in raw soybeans (Abdelgadir et al., 1984). The latter emphasizes the importance of feeding the appropriate protein source during the weaning phase as well (Drackley, 2008), especially because there is not an immune adaptation to antigenic soy and, even more, calves show a greater immunological response after previous sensitization with antigenic soy (Barratt et al., 1978).

The objective of this article is to review the characteristics of the most important ANF present in soybeans, their effects on the digestive and overall health of young calves, and the basics of the current available processing methods to inactivate and reduce the action of those ANF. In addition, we review the literature to examine how the different processing methods of soy protein affect feed digestibility and performance in young calves.

\section{IMPLICATIONS OF ANTINUTRITIONAL FACTORS IN SOYBEANS}

\section{ANF in Soybeans}

Soybeans are recognized as a valuable source of protein for ruminants and nonruminants. However, the nutritional value of soy is marked by the quantity and availability of AA and by the presence of the naturally occurring ANF. Protease inhibitors, lectins, antigenic proteins, tannins, polyphenols, oligosaccharides, goitrogens, phytates, and antivitamins are some of the ANF with a significant negative effect on calf performance (Huisman and Jansman, 1991). Although they are nontoxic, these factors cause negative physiological responses in the animal (Liener, 1981). Whether individually or in association, these components affect mainly protein digestion and absorption but also carbohydrate digestion and mineral and vitamin bioavailability (Lallès, 1993). Protease inhibitors are the best studied of these factors; however, the other ANF should not be overlooked.

Protease Inhibitors. Protease inhibitors are classified as the Kunitz inhibitor of trypsin, and the Bowman-Birk inhibitor of chymotrypsin and trypsin (Friedman and Brandon, 2001). The structure of the Kunitz inhibitor is a single polypeptide chain composed of around 200 AA (Liener and Kakade, 1969). The Kunitz inhibitor is easily denatured by heat, acid, or alkali, and at a low $\mathrm{pH}$ it can be hydrolyzed by pepsin (Liener and Kakade, 1969). By contrast, the high content of Cys residues arranged as disulfide bonds of the Bowman-Birk inhibitor provides it with high resistance to denaturation by heat, acid, or alkali, and to proteolytic enzymes (Liener and Kakade, 1969; Lallès, 1993). Among all the protease inhibitors present in legume seeds, trypsin inhibitors are the ones that have the greatest influence in monogastric animals (Huisman and Jansman, 1991). Whole soybeans can contain between 17 and $27 \mathrm{mg}$ of trypsin inhibitor per gram or 86 trypsin inhibitor units per milligram (Liener, 1981). These molecules attach to the enzyme, and the resulting complex is not easily disassociated because of a very tight bond. Digestibility of soy and nonsoy protein therefore will be affected negatively during the digestion process (Tukur et al., 1993). Calf performance will be diminished when protease inhibitor concentrations in soy protein are elevated (Dawson et al., 1988).

Lectins. In defatted soybean flour, lectins account for 1 to $3 \%$ of the protein (Liener, 1981). These components, also found in other legume seeds, are glycoproteins highly resistant to digestion. Lectins alter the morphology of the epithelium, intestinal permeability, and transport of nutrients, by binding to the mucosa of the gut due to their strong affinity for carbohydrates on cell surfaces (Friedman and Brandon, 2001). Lectins are known to induce a response of the local and humoral immune systems and to interfere with the bacterial ecology of the small intestine. Even though not all lectins show the same degree of severe effects, the binding of lectins with the membrane receptors of epithelial cells produces important changes in the digestion and absorption of nutrients and in the metabolism of brush border cells (Huisman et al., 1989).

$D i$ - and Oligosaccharides. The young calf lacks the enzymes required to digest some of the di- and oligosaccharides present in soybeans, such as sucrose, raffinose, stachyose, and verbascose. The passage of these intact carbohydrates into the intestine may increase the flow of digesta due to their osmotic effect in the small intestine. These carbohydrates will also increase the appearance of flatulences because they are a substrate for microbial fermentation in the large intestine (Sissons, 1982).

Phenolic Acids. These compounds are known to activate synthesis of prostaglandins and other subfamilies of eicosanoids from arachidonic acid. Large amounts of released prostaglandins are associated with gastrointestinal cramps and diarrhea due to their effect on the intestinal muscle layers. In addition, prostaglandins alter water and electrolyte transport across the mucosa (Waller, 1973) and inhibit the reabsorption of water and electrolytes, which increases the digesta fluid content and aggravates diarrhea (Gardner et al., 1990). Phenolic compounds in hexane-extracted soy protein 
concentrate (SPC) also increased heart and respiratory rates in comparison with the already elevated values from calves fed ethanol-extracted SPC (without phenolic compounds) when compared with milk-fed calves (Gardner et al., 1990). Detoxification of polyphenolic compounds after absorption requires methylation and therefore increases the utilization of Met, which is at a low concentration in soy protein (Huisman et al., 1989).

Goitrogens. The component causing goiter is still unknown, but unheated soybean does cause an enlargement of the thyroid gland by inhibiting its iodine uptake in monogastric animals (Liener, 1994) and in calves born from cows not receiving supplemental iodine (Hemken et al., 1971). Heating of soybeans can only partially counteract this effect, and proteolytic digestion seems to be ineffective. However, iodine supplementation reverses goitrogenic activity (Hemken et al., 1971).

Phytates. Phytic acid forms chelates with metal ions such as calcium, magnesium, zinc, copper, and iron (Liener, 1981). The chelation reduces mineral bioavailability, because such complexes are not readily absorbable (O'Dell, 1979). Phytic acid forms strong complexes with certain proteins, which makes them less susceptible to hydrolysis (O'Dell, 1979). Removal of phytic acid can be achieved via heat, through enzymatic hydrolysis, or with acid or alkaline conditions during protein precipitation (O'Dell, 1979; Liener, 1981).

Antivitamins. Lipoxygenase in raw soybeans oxidizes and destroys carotene. Inclusion of $30 \%$ raw soybean in the diet reduced blood concentrations of carotene and vitamin A in dairy calves (Liener, 1994). Raw soybeans also have rachitogenic properties that can be ameliorated by supplementing with vitamin $\mathrm{D}_{3}$, calcium, and phosphorus, or by simply heating the soybean (Liener, 1981). Moreover, raw soybean can increase the requirements for vitamin $\mathrm{E}$ and $\mathrm{B}_{12}$, by components that are still not well known (Liener, 1981, 1994).

Saponins. These components are steroid or triterpenoid glycosides. Some saponins from certain plants seem to increase intestinal permeability (Huisman et al., 1989). However, feeding soybean saponins at 3 to 5 times the amount typically present in a soybean diet failed to inhibit growth in chicks, rats, and mice, which places saponins probably out of the ANF of concern for calves (Liener, 1994).

Antigenic Compounds. Some ANF, such as protease inhibitors and lectins, induce specific antibody synthesis mediated by gastrointestinal response (Lallès, 1993). Even though soybean albumins seem not to cause such a response, the major protein storage globulins glycinin and $\beta$-conglycinin are associated with an allergenic response (Sissons, 1982). Analysis of wheal growths from intradermal injections in calves revealed an allergic response to milk with different concentrations of antigenic soybean products (Gardner et al., 1990). After sensitization by feeding antigenic soy protein (heated soy flour), calves also show a similar immunological response to other food protein such as ovalbumin (Kilshaw, 1981).

\section{Effects of ANF on Calf Digestive Metabolism}

Inactivation of trypsin triggers the release of cholecystokinin from the pancreas, which stimulates the secretion of more proteases from the acinar cells and causes hypertrophy of the pancreas (Huisman et al., 1989). Unlike in other mammals, however, protease inhibitors in soybeans do not induce these changes in calves (Lallès, 1993). Moreover, calves have shown a decrease in trypsin (Khorasani et al., 1989) and chymotrypsin (Guilloteau et al., 1986a) secretion when they were fed with soy flour, SPC, and soy protein isolate (SPI; Lallès, 1993). A reduced pancreatic secretion will reduce soy protein and nonsoy protein digestibility (Tukur et al., 1993). In addition, the major globulins in soybeans, glycinin and $\beta$-conglycinin, are very resistant to proteolysis (Sissons, 1982). Secretion of gastric acid and digestive enzymes, such as hydrochloric acid, rennin, and pepsin, is reduced when soybean proteins are fed replacing milk proteins (Sissons, 1982). Soy protein in SPC reduced intestinal absorption by decreasing villus length, enterocyte proliferation, and secretion of intestinal digestive enzymes (Dawson et al., 1988; Grant et al., 1989; Drackley et al., 2006). In addition, soy protein also increases mucin (Montagne et al., 2000) and other endogenous protein secretions (Montagne et al., 2001).

Protease inhibitors, lectins, and soy globulins are the main molecules responsible for the induction of soyspecific antibody synthesis (Sissons, 1982). Besides a humoral immune response triggered by glycinin and $\beta$-conglycinin (Dawson et al., 1988), glycinin has a linear negative effect on apparent small intestine protein digestibility (Tukur et al., 1993). Nevertheless, both globulins contribute to a reduction in calf performance (Dawson et al., 1988), and calves do not seem to develop a tolerance to antigenic soy proteins despite a prolonged exposure (Barratt et al., 1978). Furthermore, prostaglandins and other eicosanoids, whose synthesis is elevated by the phenolic compounds in soybeans, are also mediators of inflammation in the bowel (Gardner et al., 1990).

The length of time that digesta stays inside the abomasum before passing through the pylorus to the small intestine is an important factor that can affect calf health and growth. Because of the absence of ca- 
sein, plant proteins do not react with rennin to induce abomasal clotting, therefore increasing the abomasal emptying rate (Colvin et al., 1969), which can reduce protein digestion (Lallès, 1993). The immune response to antigenic soy protein also seems to be the origin of the motor dysfunction of the gut causing a delayed abomasal emptying (Smith and Sissons, 1975; Lallès et al., 1999). Soy-fed calves showed altered concentrations of some of the hormones involved in gut motility, such as higher concentrations of somatostatin and cholecystokinin and lower concentrations of gastric inhibitor peptide in circulation (Guilloteau et al., 1986a). The movement of digesta through the intestine is initiated by a muscular contraction that begins in the duodenum and continues toward the lower intestine (Sissons, 1982). By monitoring myoelectrial activity in the intestine, it was found that calves fed an antigenic soybean meal that supplied up to $35 \%$ of the MR protein manifested an increased frequency of intestinal contraction, which contributed to diarrhea occurrence because water ileal flow surpassed the capacity of absorption in the large intestine (Lallès et al., 1995a). The disparity of results found in the literature suggests that the a priori inhibitory effect of antigenic soy protein on abomasal emptying rate will depend on the type of soy product fed (Smith and Sissons, 1975).

\section{Processing Methods for Soybeans}

Processing of soybeans can reduce the adverse effects caused by ANF. The ANF can be classified as heat-labile or heat-stable; however, in some cases only partial inactivation may occur, so the classification into one of these groups is not totally strict (Liener, 1981). Nevertheless, heat treatment is a key method that constitutes the first step among the different processing methods available.

Heating. Heat treatment (e.g., boiling, toasting, extrusion) is the most common process applied to the commercially available forms of soy products (Liener, 1981). Heat application reduces the action of protease inhibitors, especially those within the Kunitz family (Lallès, 1993). However, after heating, soy flour retains 5 to $20 \%$ of its initial inhibitory capacity (Friedman and Brandon, 2001). Excessive heating can result in loss of nutritional value by the formation of undesirable products such as the glyco-AA fructosyl-lysine and the cross-linked AA lysinoalanine, which is a nephrotoxic substance. Both products are derived from the Maillard reaction and are not nutritionally available. Bioavailable lysine can be reduced by 78 to $85 \%$ due to excessive heating (Mao et al., 1993). Heating and toasting of soybean protein also denatures lectins (Caugant et al., 1994), which considerably increases its nutritive value
(Liener, 1981) and increases the concentration of RUP (Giallongo et al., 2015).

Hot Aqueous-Ethanol Extraction. An SPC (66 to $71 \% \mathrm{CP}$ ) extracted with hot aqueous ethanol does not contain immunologically active glycinin and $\beta$-conglycin (Lallès, 1993). However, small variations to this method of extraction may result in substantial differences in the antigenic potential of the product. Extraction of soy protein with 65 to $70 \%$ ethanol at $80^{\circ} \mathrm{C}$ for $2 \mathrm{~h}$ resulted in the minimum antigenic activity detected (Sissons, 1982). In addition, this treatment removes oligosaccharides soluble in ethanol (Caugant et al., 1994). As a result, SPC is highly digestible and apparently does not trigger common digestive disorders found with soybean flour, which results in better calf performance (Sissons, 1982; Caugant et al., 1994; Lallès et al., 1995a).

Protein Isolation. Soy protein isolates contain a minimum of $90 \%$ protein (Gardner et al., 1990). Isolates are formed by precipitation of the protein with acid after removal of the insoluble protein and polysaccharides with water plus alkali at a $\mathrm{pH}$ of 7 to 8.5 (Singh et al., 2008). Protein isolation does not seem to inactivate glycinin and $\beta$-conglycin. However, it considerably reduces the concentration of active protease inhibitors (Liener, 1981; Lallès, 1993), although sometimes not completely (Khorasani et al., 1989).

Microbial Treatment. Proteins and carbohydrates during induced microbial treatment (i.e., fermentation) undergo an extensive breakdown into peptides of low molecular weight, AA, oligosaccharides, and monosaccharides (Kiers et al., 2000). Fermentation also reduces the presence of certain ANF, such as trypsin inhibitors (Feng et al., 2007), mainly because heating of soybeans is one of the steps before fermentation (Liener, 1981). Even more, fermentation slightly increases the trypsininhibitory capacity due to the release of certain fatty acids during the cooking process (Wang et al., 1975). Fermentation also reduces the concentration of oligosaccharides such as raffinose and stachyose (Chompreeda and Fields, 1984). Protein fermentation with $\mathrm{Ba}$ cillus spp. achieved a complete breakdown of glycinin and $\beta$-conglycin into their subunits, which may have contributed to an increase of in vitro digestibility (Kiers et al., 2000). Fermentation of soy protein releases bioactive components that enhance the immune system response and have many other health benefits (Chatterjee et al., 2018). Calves fed fermented soybean meal (FSBM) showed less immune response to the antigens glycine and $\beta$-conglycin than did calves fed only heated or extruded soybean (Mir et al., 1993). Moreover, supplementation with Bacillus subtilis natto, a bacterium isolated from FSBM, increased calf immune function (higher serum IgG and IFN- $\gamma$ ) and promoted better 
growth rates (Sun et al., 2010). In addition, FSBM contains a high concentration of vitamin $\mathrm{K}$, which is involved in calcium metabolism in bone, and is also free of the flatulence factors found in soybean (Liener, 1981).

\section{CALF PERFORMANCE WITH SOY-BASED FEEDS}

\section{Small Intestinal Digestibility of Soy Protein}

Apparent small intestine digestibility (AID) of soy protein in MR has been generally reported to be diminished compared with that of milk proteins (Table 1 ). This difference could be due to some of the factors reviewed previously, such as the effects of ANF and antigenic soy proteins in abomasal emptying, digestive secretions, intestinal tissue morphology and permeability, and flow of digesta (Kilshaw, 1981; Lallès, 1993; Drackley, 2008). Plant proteins can also influence apparent digestibility due to a greater synthesis of indigestible endogenous protein (Montagne et al., 2000) or to the presence of the aforementioned ANF that will alter the digestive and absorptive capacity of the intestinal epithelium (Lallès et al., 1999). Moreover, microbial fermentation in the large intestine will alter the $\mathrm{N}$ concentration and the profile of AA in feces, which will cause erroneous values for total-tract digestibilities of individual AA (Khorasani et al., 1989). The calculation of small intestine digestibility (SID) values is therefore a more accurate method to evaluate protein quality in feed ingredients for young dairy calves than the use of total-tract digestibility. Research using this technique was abundant in the past, but to our knowledge only 1 experiment has been reported in the last 2 decades using this method of digestibility determination (Montagne et al., 2003).

Early work by Gorrill and Nicholson (1972) found lower AID of DM, N, and gross energy with an MR containing $22 \% \mathrm{SPC}$ in comparison with an all spraydried skim milk powder MR. Guilloteau et al. (1986b) compared the AID of 3 different MR that differed in the source of protein: (1) the control with spray-dried skim milk powder as unique source, and 2 experimental MR with (2) ethanol-extracted SPC and (3) fish meal supplying 44 and $30.5 \%$ of the protein, respectively. The AID of DM, OM, N, fat, ash, and N-free extract were lower for the MR with ethanol-extracted SPC than for the others with fish or milk protein. Digestibility of total AA was greater for milk than for soybean protein, especially for His, Pro, Glu, Asp, and Val (Guilloteau et al., 1986b). Similarly, Khorasani et al. (1989) reported lower AID of CP and most AA when spray-dried skim milk powder was $100 \%$ substituted with SPI. In contrast with the previous experiment by
Guilloteau et al. (1986b), no differences in DM digestibility were found, which could be a result of improved digestibility of SPI compared with ethanol-extracted SPC (Khorasani et al., 1989). In addition to the same individual AA (except Asp) affected in the study by Guilloteau et al. (1986b), the authors also found large differences of AID for Ile, Leu, Lys, Met, Ser, and Tyr (Khorasani et al., 1989). The relevance of the processing of soybean protein was also demonstrated by Tukur et al. (1993), who found lower OM, CP, and ash AID when spray-dried skim milk powder was replaced by heated soybean flour up to $50 \%$ of the CP, but not when skim milk was replaced with ethanol-extracted SPC. Caugant et al. (1993) also found an effect of soy protein processing on AA digestibility. Although a heated soy flour-based diet showed significant differences in all AA compared with an all-milk diet, feeding an MR with an ethanol-extracted SPC improved SID of Lys, Phe, Ile, Met, and total N (Caugant et al., 1993). Substitution of $50 \%$ of the skim milk powder with heated and hexane-extracted SPC also resulted in lower DM, CP, and AA AID (Kanjanapruthipong, 1998). It is important to note that hexane extraction is not as efficient as using ethanol to remove phenolic compounds in soybean protein (Gardner et al., 1990).

Comparisons between AID of $\mathrm{CP}$ or AA from different feed sources can lead to misleading conclusions because a relatively important percentage of the digesta $\mathrm{CP}$ and $\mathrm{AA}$ that have not been reabsorbed at the ileum are secreted or appear endogenously (Stein et al., 2007). Endogenous AA or CP losses are mainly formed by mucin, sloughed cells, serum albumin, digestive enzymes, amides, ingested hair, and bacteria during healthy conditions (Montagne et al., 2001). In milk-fed calves, the estimated AA profile of endogenous protein losses in digesta is similar between diets with plant or milk proteins, as well as an N-free MR (Montagne et al., 2001), which can facilitate estimation of the total endogenous protein flow. Endogenous losses of $\mathrm{N}$ or AA are classified into basal and specific losses (Stein et al., 2007). Endogenous basal losses are not influenced by the composition of the diet and generally increase as DMI increases at the same BW. However, the flow of specific losses depends on the composition of the diet and increases when fiber, undigested protein, and ANF flows increase across the digestive tract. Feeding an $\mathrm{N}$-free diet allows us to obtain the endogenous basal losses with which we are able to calculate standard SID (Montagne et al., 2003; Stein et al., 2007). In contrast, methods for the estimation of specific endogenous losses (e.g., homoarginine and isotope tracer dilution techniques) are laborious and expensive, and both methods have other important limitations. However, a mathematical model has been developed by Duvaux 
et al. (1990) to estimate the flow of total endogenous losses using the AA profile of the different proteins that constitute the ileal digesta. The authors combined a multiple regression analysis with the calculation of the $\chi^{2}$ distance between the AA profile from dietary, endogenous, and microbial protein and AA profile from the digesta. The lower the distance of $\chi^{2}$, the higher the similarity between the proteins compared (Guilloteau et al., 1986b). As a result, true small intestine digestibility (TID) of dietary proteins can be estimated because the flow of AA at the ileum can be corrected by the total endogenous losses (Stein et al., 2007).

Montagne et al. (2001) found that AID of OM $(92 \%)$ and ash (69\%) were higher with skim milk powder than with ethanol-extracted SPC, but only tended to be higher than with hydrolyzed SPI. However, the opposite trend was found with $\mathrm{CP}$ and AA, where the hydrolyzed SPI diet showed a significantly lower AID and SID and only a tendency for the diet with SPC. In contrast, when TID were estimated, both soy proteins showed a significantly lower value than skim milk powder (Montagne et al., 2001). Standard and TID of CP and AA at the ileum were very high (100 and 99\%, respectively) with the skim milk diet, in close agreement with values measured with H-labeled milk protein by Sedgman et al. (1985). The extremely high values found by Montagne et al. (2001) should be considered carefully because these researchers infused the reconstituted diets continuously through an abomasal catheter and also added sodium citrate to avoid clogging, to obtain a slow and continuous transit across the digestive tract, which may have increased the rate of digestion and absorption. Nevertheless, their findings indicate that endogenous losses of $\mathrm{N}$ and AA were very low or null with the milk-based diet. However, SID and TID with both soy protein products were greater than AID, which means that a substantial increase in endogenous losses occurred (Montagne et al., 2001). Considering that both the SPC and the hydrolyzed SPI should have had very low concentrations of trypsin inhibitors and antigenic proteins, it is likely the interaction of the gut with other components in the diet, such as nonantigenic proteins and peptides (Lallès et al., 1999), oligosaccharides, or fiber (Stein et al., 2007), stimulated the synthesis of endogenous protein secretions.

In weaned calves, when considering both duodenal and ileal flow of CP and AA, Khorasani et al. (1990) reported that AID of CP and AA (except Met and Glu) were greater for calves fed soybean meal (SBM) than for those fed canola meal-based calf starter, and no differences were detected in pancreatic juice volume or secretion of protein, chymotrypsin, and trypsin. These findings indicate that, at least in the ruminant calf, the source of protein or ANF does not exert an important influence on protease secretion (Khorasani et al., 1990), unlike what occurs in the preruminant calf (Lallès, 1993).

\section{Effects of Soy Protein on Calf Performance}

Correct selection of treated soybean protein to feed pre- and postweaning calves can play a tremendous role in calf health status and growth rates. Whether through improved CP and AA digestibility or through a lesser immune response to antigenic soybean compounds, calf growth and health scores are the parameters that best represent the effectiveness of the test feed ingredient. Selecting the proper feed ingredient for MR and calf starter can have an economic impact in calf-rearing programs and will also affect the long-term productivity of the animal (Rauba et al., 2019).

It has long been known that feeding untreated (raw) soybean protein to the preruminant calf can have negative consequences for calf performance (Shoptaw, 1936). Calves fed MR with acid- or alkali-treated SBM as the protein source grew at a rate almost double that of calves fed MR with untreated SBM (Colvin et al., 1969). Early work by Morrill et al. (1971) found that an SPC could replace $22 \%$ of the protein supplied by dry whey, but with $44 \%$ substituted the ADG diminished. In contrast, Gorrill and Nicholson (1972) showed no difference in ADG between calves fed skim milk powder or a mix with $70 \%$ of the protein provided by the same SPC until 7 wk of life. In a similar experimental design, the authors found that calves fed the same SPC-based MR were less efficient because they consumed more hay but did not grow more before weaning (Gorrill and Nicholson, 1969). However, it is now known that the type of forage offered and the way the forage is offered play an important role in calf growth and gastrointestinal tract development, and have long-term effects on growth and first-lactation milk response (Castells et al., 2015). In fact, the calves fed the SPC-based MR grew less after weaning even when they had the same DMI as the all-milk-fed calves (Gorrill and Nicholson, 1969). The numerous differences between the feeding regimens and experimental designs of Gorrill et al. (1972) and Morrill et al. (1971) experiments make it difficult to find an explanation for the effectiveness of SPC as a substitute for milk proteins. After a series of experiments comparing milk proteins against toasted and alkali-treated soy protein in MR, Nitsan et al. (1972) concluded that when the ratio of soy to milk protein is between 50:50 and 88:12, the growth of soy-fed calves was up to $85 \%$ of the control calves. However, when solid feed was also offered, the growth rate of the calves 
fed soy protein improved, probably due to a higher ingestion and absorption of digestible nutrients (Nitsan et al., 1972).

Later attempts to identify milk protein substitutes for MR also found detrimental effects in calf performance when the most common soy products were studied. Nevertheless, feeding raw or heated soybeans were the options that yielded the worst performance compared with other soy treatments. Protein efficiency and ADG were lower in calves fed MR when the only source of protein was SPC or defatted or full-fat soy flour than when calves were fed with dried skim milk powder. No differences were detected in incidence of diarrhea, and the authors concluded that the differences of performance were a consequence of poor CP digestibility and protein retention (Akinyele and Harshbarger, 1983). Abdelgadir et al. (1984) also found lower $\mathrm{N}$ retention and weight gain when calves were fed raw versus heated ground soybeans. Similarly, Guilloteau et al. (1986a) reported lower weight gain with ethanol-extracted SPC instead of skim milk. However, in Guilloteau et al. (1986a), results may be confounded by the inclusion of milk whey in the MR containing SPC, and by calves in the SPC group having a much lower MR intake due to greater refusals in this group. Dawson et al. (1988) compared the effects on growth of milk protein (whey) against different soy products: SPC, heated soy flour, and toasted soy flour $(26,33$, and $33 \%$ inclusion, respectively). Growth until 6 wk of life, especially during the first $3 \mathrm{wk}$, was greater for calves fed only milk proteins compared with calves fed any of the soy products. Among those, toasted soy flour and SPC obtained better growth rates than heated soy flour. Substitution of $60 \%$ of the whey protein with SPC resulted in lower ADG (344 vs. $281 \mathrm{~g} / \mathrm{d}$ ), as was also the case when SPC was supplemented with Gln $(282 \mathrm{~g} / \mathrm{d}$; Drackley et al., 2006). Heated and ethanol- or hexane-extracted SPC at an inclusion rate in MR of 18.5 and $5.5 \%$, respectively, reduced calf weight gain and increased diarrhea incidence plus heart and respiration rates compared with cow milk (Gardner et al., 1990).

A novel feed ingredient such as soymilk has also been tested as an alternative to milk proteins (Ghorbani et al., 2007). Soymilk is obtained by extraction of the protein concentrate after cooking soybeans in water (Ghorbani et al., 2007). An inclusion of $25 \%$ soymilk (wet basis) resulted in a substantially lower (but nonsignificant) ADG (425 vs. $331 \mathrm{~g} / \mathrm{d}$ ) in the first $2 \mathrm{wk}$, whereas calves fed the MR with a $50 \%$ inclusion had a significantly lower ADG (425 vs. $90 \mathrm{~g} / \mathrm{d}$ ). Soymilkfed calves (25 and $50 \%$ inclusion) reached the weaning criterion (intake of $900 \mathrm{~g} / \mathrm{d}$ for $2 \mathrm{wk}$ ) sooner but with lower BW. Probably, due to the low nutrient content and high concentration of ANF in soymilk (Anderson and Wolf, 1995), intake of starter was crucial to sustain this moderate performance result.

Nevertheless, it has also been reported that diets with relatively moderate to high inclusion of certain soy products resulted in no detrimental effects compared with milk proteins. Grant et al. (1989) found no effect of the diet on growth or fecal scores with an inclusion of $15 \%$ of SPC ( $20 \%$ of the CP). Also, Huang at al. (2015) supplied $70 \%$ of the protein in the MR with SPC and found no differences in ADG or feed efficiency. Additionally, a diet with $86 \%$ of the protein substituted by an SPI nearly free of trypsin inhibitor resulted in the same growth rates and no diarrhea incidence compared with calves on an all-milk diet (Gorrill and Thomas, 1967). In contrast, in the same study, calves fed an MR with lower inclusion of SPC (50\%) manifested high incidence of diarrhea and lower rates of weight gain due to a higher concentration of trypsin inhibitors (Gorrill and Thomas, 1967). Mir et al. (1991) also demonstrated the relevance of proper processing of the soy protein included in MR. In this case, $43 \%$ of the $\mathrm{CP}$ was substituted with several soy products. Extruded, ethanol-extracted, and fermented soy protein resulted in similar results to those of the all-milk diet in terms of weight gain and feed and protein efficiency, whereas heated soy protein did not (Mir et al., 1991). Lallès et al. (1995b) showed that calves fed nonantigenic soybean flour or concentrate gained more weight than their counterparts fed the antigenic versions of the same soy products.

The removal of antigenic proteins and protease inhibitors is important for acceptable calf performance, and further processing that improves digestibility by denaturing protein, such as fermentation (Mir et al., 1991) and hydrolysis (Lallès et al., 1995b), seems to consistently result in improved growth rates compared with other soy products. In a different study, Lallès et al. (1995c) confirmed that feeding an MR with a hydrolyzed SPI that supplied $56 \%$ of the protein resulted in the same live and carcass weight as the all-milk group, with no differences in diarrhea incidence. Low inclusion of FSBM has also shown positive results, especially in terms of digestive health and immune response. Kim et al. (2010) fed a calf starter with 5\% Aspergillus oryzae-fermented SBM to preweaning calves and challenged them with a microbial infection $(1 \mathrm{~mL}$ of porcine hog cholera and Erysipelothrix insidiossa live vaccine) at $21 \mathrm{~d}$ of age. No differences in DMI or weight gain compared with the control group were detected (100\% regular SBM). However, calves fed the FSBM showed an improved immune response to the microbial challenge, as reflected by the lower incidence of diarrhea, the higher production of haptoglobin, and the production of the antigen-specific serum protein $\operatorname{IgA}$ 
(Kim et al., 2010). Senevirathne et al. (2017) found a slight increase in pre- and postweaning body weight gain, with less DMI, when feeding an aerobically FSBM with a non-yeast fungus. However, these results must be considered carefully, as the experimental starter had a greater CP concentration than the control, and they were comparing 2 different planes of nutrition as well. Surprisingly, the supplementation of an MR with $B$. subtilis natto that was extracted from FSBM resulted in greater ADG (310 vs. $350 \mathrm{~g} / \mathrm{d}$ ), lower feed-to-gain ratio (2.58 vs. 2.17), and reduced age at weaning (58 vs. 51 d; Sun et al., 2010). Sun et al. (2010) attributed these findings to improvement of calf immune function (greater concentrations of serum IgG and IFN- $\gamma$ ) caused by the probiotic effect of B. subtilis natto.

At first glance, untreated soybean does not seem to greatly affect growth in calves with a fully functional rumen. Extrusion of soybean reduces ANF while increasing the concentration of RUP (Giallongo et al., 2015). However, ZeidAli-Nejad et al. (2018) found no differences in any of the measured growth parameters when calf starters with different inclusions of extruded SBM $(0,9$, and 19\%) were fed to calves either preor postweaning. Nevertheless, sometimes minimally treated soybean protein does increase efficiency of nutrients and performance (Abdelgadir et al., 1984), especially when further processing such as soy protein fermentation is applied. Kim et al. (2012) included 5\% A. oryzae-fermented SBM in calf starter. Calves fed FSBM consumed more starter before weaning and more milk until wk 4, gained more weight from wk 4 until weaning, and had improved fecal and health scores preand postweaning. Furthermore, FSBM calves showed an attenuated response of proinflammatory cytokines (TNF- $\alpha$ and IL-6), acute-phase proteins (haptoglobin and serum amyloid A), and stress-related hormones (cortisol). Similarly, Kwon et al. (2011) found a better response of the immune system to an LPS challenge in calves fed FSBM instead of conventional SBM. Unlike the control group, calves fed the FSBM diet showed no hematological change (platelet concentration). In addition, FSBM calves manifested lower release of cortisol, greater concentration of the LPS-specific IgG and IgA, and higher increase in serum haptoglobin concentration than the SBM group. However, Wolfswinkel (2009) found no differences in calf performance or in vitro immune response between calves fed $A$. oryzae- and $B$. subtilis-fermented SBM or regular SBM. However, in the latter study, the high proportion of "sick" calves (defined as a calf that received 1 or more medical treatments; $59 \%$ of all calves enrolled) and the very early weaning age ( $\sim 22 \mathrm{~d}$ of age) potentially could have masked any possible diet effect. Despite the multiple bioactive compounds in FSBM that could boost the im- mune response in these studies (Chatterjee et al., 2018), the greater concentration of AA in FSBM (Chompreeda and Fields, 1984; Kim et al., 2012) may also have played an important role in the improved response of the immune system (Kwon et al., 2011).

Even though research has focused on the major effects of ANF, other characteristics of the nonantigenic protein (e.g., AA concentration, peptide size, structure) also may have contributed to the differences found in digestibility and performance between diets based on milk or soy proteins. For instance, formulations of isonitrogenous MR using soy protein as a partial substitute for milk protein have resulted in diets with AA concentrations lower than those of an all-milk diet (Khorasani et al., 1989; Caugant et al., 1993; Mir et al., 1993; Kanjanapruthipong, 1998). Nevertheless, depending on the soy product and its inclusion rate, a soy-based MR could have a reduced difference or greater concentrations of certain AA, such as Cys, Arg, Gly, Asp, Ala, and Phe.

\section{CONCLUSIONS}

The great diversity of soy products and inclusion rates evaluated so far in the literature make it difficult to draw a conclusion about the effectiveness of soy protein in young dairy calves. The different parameters involved in each of the soy processing methods can have a major impact on the efficient removal of ANF and antigenic proteins and, therefore, on the performance of calves. Nevertheless, we can establish that certain processing methods can improve the quality of the product as an alternative to milk protein. A moderate to high inclusion of an SPI or ethanolextracted SPC with minimum or null amounts of ANF can obtain satisfactory results. Furthermore, the few studies where microbial-treated or FSBM was fed also reveal a promising future for this type of ingredient. Conventional processing methods of soy protein can fail to completely remove or inactivate ANF and are able only to increase the proportion of RUP that reaches the small intestine. However, microbial treatment also increases the concentration of AA and small peptides, and triggers the release of still-unexplored bioactive compounds that can benefit multiple aspects of the calf immune and digestive system. Microbial treatment of soy proteins constitutes an alternative to conventionally treated soy proteins during the transition and postweaning period, and could possibly be a substitute for milk proteins in MR. More research is needed to evaluate novel soy products in growth and health during the growing phase and their long-term effects. Regardless of the treatment, the dated literature on soy protein as an alternative to milk proteins may not optimally 
represent the current variety of soybean treatments available. In addition, the modern calf industry could benefit from more updated and reliable experimental designs, greater sample sizes, and more accurate digestibility measurement techniques. Further research about improved or new processing methods of soy protein has great potential to create opportunity for the calf-raising industry to use more economically efficient ingredients within modern calf nutrition programs.

\section{ACKNOWLEDGMENTS}

The authors have not stated any conflicts of interest.

\section{REFERENCES}

Abdelgadir, I. E. O., J. L. Morrill, J. A. Stutts, M. B. Morrill, D. E. Johnson, and K. C. Behnke. 1984. Effect of processing temperature on utilization of whole soybeans by calves. J. Dairy Sci. 67:25542559. https://doi.org/10.3168/jds.S0022-0302(84)81612-4.

Akinyele, I. O., and K. E. Harshbarger. 1983. Performance of young calves fed soybean protein replacers. J. Dairy Sci. 66:825-832. https://doi.org/10.3168/jds.S0022-0302(83)81863-3.

Anderson, R. L., and W. J. Wolf. 1995. Compositional changes in trypsin inhibitors, phytic acid, saponins and isoflavones related to soybean processing. J. Nutr. 125:581S-588S. https://doi.org/10 .1093/jn/125.3_Suppl.581S.

Barratt, M. E., P. J. Strachan, and P. Porter. 1978. Antibody mechanisms implicated in digestive disturbances following ingestion of soya protein in calves and piglets. Clin. Exp. Immunol. 31:305-312.

Barratt, M.E.J., and P. Porter. 1979. Immunoglobulin classes implicated in intestinal disturbances of calves associated with soya protein antigens. J. Immunol. 123:676-680.

Castells, L., A. Bach, and M. Terré. 2015. Short- and long-term effects of forage supplementation of calves during the preweaning period on performance, reproduction, and milk yield at first lactation. J. Dairy Sci. 98:4748-4753. https://doi.org/10.3168/jds.2014-9025.

Caugant, I., H. V. Petit, M. Ivan, C. Bard, L. Savoie, R. Toullec, S. Thirouin, and M. Yvon. 1994. In vivo and in vitro gastric emptying of milk replacers containing soybean proteins. J. Dairy Sci. 77:533-540. https://doi.org/10.3168/jds.S0022-0302(94)76981-2.

Caugant, I., R. Toullec, M. Formal, P. Guilloteau, and L. Savoie. 1993. Digestibility and amino acid composition of digesta at the end of the ileum in preruminant calves fed soybean protein. Reprod. Nutr. Dev. 33:335-347. https://doi.org/10.1051/rnd:19930403.

Chatterjee, C., S. Gleddie, and C.-W. Xiao. 2018. Soybean bioactive peptides and their functional properties. Nutrients 10:1211. https: //doi.org/10.3390/nu10091211.

Chompreeda, P. T., and M. L. Fields. 1984. Effects of heat and natural fermentation on amino acids, flatus producing compounds, lipid oxidation and trypsin inhibitor in blends of soybean and cornmeal. J. Food Sci. 49:563-565. https://doi.org/10.1111/j.1365-2621.1984 .tb12468.x.

Colvin, B. M., R. A. Lowe, and H. A. Ramsey. 1969. Passage of digesta from the abomasum of a calf fed soy flour milk replacers and whole milk. J. Dairy Sci. 52:687-688. https://doi.org/10.3168/jds.S0022 -0302(69)86629-4.

Dawson, D. P., J. L. Morrill, P. G. Reddy, H. C. Minocha, and H. A. Ramsey. 1988. Soy protein concentrate and heated soy flours as protein sources in milk replacer for preruminant calves. J. Dairy Sci. 71:1301-1309. https://doi.org/10.3168/jds.S0022 -0302(88)79687-3.

Drackley, J. K. 2008. Calf nutrition from birth to breeding. Vet. Clin. North Am. Food Anim. Pract. 24:55-86. https://doi.org/10.1016/ j.cvfa.2008.01.001.
Drackley, J. K., R. M. Blome, K. S. Bartlett, and K. L. Bailey. 2006. Supplementation of 1\% L-glutamine to milk replacer does not overcome the growth depression in calves caused by soy protein concentrate. J. Dairy Sci. 89:1688-1693. https://doi.org/10.3168/jds .S0022-0302(06)72236-6.

Duvaux, C., P. Guilloteau, R. Toullec, and J. W. Sissons. 1990. A new method of estimating the proportions of different proteins in a mixture using amino-acid profiles: Application to undigested proteins in the preruminant calf. Ann. Zootech. 39:9-18. https:// doi.org/10.1051/animres:19900102.

Feng, J., X. Liu, Z. R. Xu, Y. P. Lu, and Y. Y. Liu. 2007. Effect of fermented soybean meal on intestinal morphology and digestive enzyme activities in weaned piglets. Dig. Dis. Sci. 52:1845-1850. https://doi.org/10.1007/s10620-006-9705-0.

Friedman, M., and D. L. Brandon. 2001. Nutritional and health benefits of soy proteins. J. Agric. Food Chem. 49:1069-1086. https:// doi.org/10.1021/jf0009246.

Gardner, R. W., M. G. Shupe, W. Brimhall, and D. J. Weber. 1990 Causes of adverse responses to soybean milk replacers in young calves. J. Dairy Sci. 73:1312-1317. https://doi.org/10.3168/jds .S0022-0302(90)78797-8.

Ghorbani, G. R., R. Kowsar, M. Alikhani, and A. Nikkhah. 2007. Soymilk as a novel milk replacer to stimulate early calf starter intake and reduce weaning age and costs. J. Dairy Sci. 90:5692-5697. https://doi.org/10.3168/jds.2007-0431.

Giallongo, F., J. Oh, T. Frederick, B. Isenberg, D. M. Kniffen, R. A. Fabin, and A. N. Hristov. 2015. Extruded soybean meal increased feed intake and milk production in dairy cows. J. Dairy Sci. 98:6471-6485. https://doi.org/10.3168/jds.2015-9786.

Gorrill, A. D., and J. W. Thomas. 1967. Body weight changes, pancreas size and enzyme activity, and proteolytic enzyme activity and protein digestion in intestinal contents from calves fed soybean and milk protein diets. J. Nutr. 92:215-223. https://doi.org/10 $.1093 / \mathrm{jn} / 92.2 .215$.

Gorrill, A. D. L., and J. W. G. Nicholson. 1969. Growth, digestibility and nitrogen retention by calves fed milk replacers containing milk and soybean proteins, supplemented with methionine. Can. J. Anim. Sci. 49:315-321. https://doi.org/10.4141/cjas69-042.

Gorrill, A. D. L., and J. W. G. Nicholson. 1972. Effects of neutralizing acid whey powder in milk replacers containing milk and soybean proteins on performance and abomasal and intestinal digestion in calves. Can. J. Anim. Sci. 52:465-476. https://doi.org/10.4141/ cjas72-055.

Gorrill, A. D. L., J. W. G. Nicholson, and H. E. Power. 1972. Effects of milk, fish, and soybean proteins in milk replacers, and feeding frequency on performance of dairy calves. Can. J. Anim. Sci. 52:321-328. https://doi.org/10.4141/cjas72-036.

Grant, A. L., R. E. Holland, J. W. Thomas, K. J. King, and J. S. Liesman. 1989. Metabolism and hormonal regulation effects of dietary amines on the small intestine in calves fed soybean protein. J. Nutr. 119:1034-1041. https://doi.org/10.1093/jn/119.7.1034.

Guilloteau, P., T. Corring, J. A. Chayvialle, C. Bernard, J. W. Sissons, R. Toullec, M. Beaufils, M. Connan, A.-M. Gueugneau, M. Lesne, J. N. Nouchet, H. E. Pedersen, and S. M. Thurston. 1986a. Effect of soya protein on digestive enzymes, gut hormone and antisoya antibody plasma levels in the preruminant calf. Reprod. Nutr. Dev. 26(2B):717-728. https://doi.org/10.1051/rnd:19860426.

Guilloteau, P., R. Toullec, J. F. Grongnet, P. Patureau-Mirand, J. Prugnaud, and D. Sauvant. 1986b. Digestion of milk, fish and soya-bean protein in the preruminant calf: Flow of digesta, apparent digestibility at the end of the ileum and amino acid composition of ileal digesta. Br. J. Nutr. 55:571-592. https://doi.org/10 .1079/BJN19860063.

Hemken, R. W., J. H. Vandersall, B. A. Sass, and J. W. Hibbs. 1971. Goitrogenic effects of a corn silage-soybean meal supplemented ration. J. Dairy Sci. 54:85-88. https://doi.org/10.3168/jds.S0022 -0302(71)85782-X.

Huang, K., Y. Tu, B. Si, G. Xu, J. Guo, F. Guo, C. Yang, and Q. Diao. 2015. Effects of protein sources for milk replacers on growth performance and serum biochemical indexes of suckling calves. Anim. Nutr. 1:349-355. https://doi.org/10.1016/j.aninu.2015.11.012. 
Huisman, J., and A. J. M. Jansman. 1991. Dietary effects and some analytical aspects of antinutritional factors in peas (Pisum sativum), common beans (Phaseolus vulgaris) and soybeans (Glycine $\max$ L.) in monogastric farm animals. A literature review. Nutr. Abstr. Rev. Ser. B 61:901-921.

Huisman, J., A. F. B. van der Poel, and I. E. Liener. 1989. Recent advances of research in antinutritional factors in legume seeds. Proceedings of the first international workshop on antinutritional factors (ANF) in legume seeds. November 23-25, 1988. Wageningen, the Netherlands. Center for Agricultural Publishing and Documentation, Wageningen, the Netherlands.

Kanjanapruthipong, J. 1998. Supplementation of milk replacers containing soy protein with threonine, methionine, and lysine in the diets of calves. J. Dairy Sci. 81:2912-2915. https://doi.org/10 $.3168 /$ jds.S0022-0302(98)75852-7.

Khorasani, G. R., L. Ozimek, W. C. Sauer, and J. J. Kennelly. 1989. Substitution of milk protein with isolated soy protein in calf milk replacers. J. Anim. Sci. 67:1634-1641. https://doi.org/10.2527/ jas1989.6761634x.

Khorasani, G. R., W. C. Sauer, L. Ozimek, and J. J. Kennelly. 1990. Digestion of soybean meal and canola meal protein and amino acids in the digestive tract of young ruminants. J. Anim. Sci. 68:3421-3428. https://doi.org/10.2527/1990.68103421x.

Kiers, J. L., A. E. A. Van Laeken, F. M. Rombouts, and M. J. R. Nout. 2000. In vitro digestibility of Bacillus fermented soya bean. Int. J. Food Microbiol. 60:163-169. https://doi.org/10.1016/S0168 $-1605(00) 00308-1$.

Kilshaw, P. J. 1981. Gastrointestinal hypersensitivity in the preruminant calf. In The Mucosal Immune System. F. J. Bourne, ed. Springer, Dordrecht, the Netherlands.

Kim, M. H., C. H. Yun, H. S. Kim, J. H. Kim, S. J. Kang, C. H. Lee, J. Y. Ko, and J. K. Ha. 2010. Effects of fermented soybean meal on growth performance, diarrheal incidence and immune-response of neonatal calves. Anim. Sci. J. 81:475-481. https://doi.org/10 .1111/j.1740-0929.2010.00760.x.

Kim, M. H., C. H. Yun, C. H. Lee, and J. K. Ha. 2012. The effects of fermented soybean meal on immunophysiological and stressrelated parameters in Holstein calves after weaning. J. Dairy Sci. 95:5203-5212. https://doi.org/10.3168/jds.2012-5317.

Kwon, I. H., M. H. Kim, C. H. Yun, J. Y. Go, C. H. Lee, H. J. Lee, W. Phipek, and J. K. Ha. 2011. Effects of fermented soybean meal on immune response of weaned calves with experimentally induced lipopolysaccharide challenge. Asian-australas. J. Anim. Sci. 24:957964. https://doi.org/10.5713/ajas.2011.10419.

Lagrange, V., D. Whitsett, and C. Burris. 2015. Global market for dairy proteins. J. Food Sci. 80(S1):A16-A22. https://doi.org/10 $.1111 / 1750-3841.12801$

Lallès, J. P. 1993. Nutritional and antinutritional aspects of soyabean and field pea proteins used in veal calf production: a review. Livest. Prod. Sci. 34:181-202. https://doi.org/10.1016/0301 -6226(93)90106-R

Lallès, J. P., D. Benkredda, and R. Toullec. 1995a. Influence of soya antigen levels in milk replacers on the disruption of intestinal motility patterns in calves sensitive to soya. Zentralbl Veterinarmed A 42:467-478. https://doi.org/10.1111/j.1439-0442.1995.tb00401.x.

Lallès, J. P., R. Toullec, P. Bouchez, and L. Roger. 1995b. Antigenicity and digestive utilization of four soya products by the preruminant calf. Livest. Prod. Sci. 41:29-38. https://doi.org/10.1016/0301 -6226(95)91056-K.

Lallès, J. P., R. Toullec, P. Branco Pardal, and J. W. Sissons. 1995c. Hydrolyzed soy protein isolate sustains high nutritional performance in veal calves. J. Dairy Sci. 78:194-204. https://doi.org/10 .3168/jds.S0022-0302(95)76629-2.

Lallès, J. P., H. M. Tukur, P. Salgado, E. N. C. Mills, M. R. A. Morgan, L. Quillien, D. Levieux, and R. Toullec. 1999. Immunochemical studies on gastric and intestinal digestion of soybean glycinin and $\beta$-conglycinin in vivo. J. Agric. Food Chem. 47:2797-2806. https://doi.org/10.1021/jf980882+.

Liener, I. E. 1981. Factors affecting the nutritional quality of soya products. J. Am. Oil Chem. Soc. 58:406-415. https://doi.org/10 $.1007 / \mathrm{BF} 02582390$.
Liener, I. E. 1994. Implications of antinutritional components in soybean foods. Crit. Rev. Food Sci. Nutr. 34:31-67. https://doi.org/ 10.1080/10408399409527649.

Liener, I. E., and M. L. Kakade. 1969. Protease inhibitors. Pages 7-68 in Toxic Constituents of Plant Foodstuffs. Academic Press, St. Paul, MN.

Mao, L.-C., K.-H. Lee, and H. F. Erbersdobler. 1993. Effects of heat treatment on lysine in soya protein. J. Sci. Food Agric. 62:307-309. https://doi.org/10.1002/jsfa.2740620316.

Mir, P. S., I. H. Burton, and J. G. Buchanan-Smith. 1991. Nutritional performance of calves fed milk replacers containing processed soybean products. Can. J. Anim. Sci. 71:97-106. https://doi.org/10 4141/cjas91-011.

Mir, P. S., J. H. Burton, E. B. Burnside, and B. N. Wilkie. 1993. Effects of processing methods for soybean meal used in milk replacers on intestinal xylose uptake and serum antibody to soybean antigen when fed to calves of various ages. Can. J. Anim. Sci 73:191-200. https://doi.org/10.4141/cjas93-019.

Mir, P. S., J. H. Burton, B. N. Willkie, and F. R. Van de Voort. 1989. Reduction of $\beta$-conglycinin antigenicity and rate of acidpepsin proteolysis of proteins in extruded or rumen fluid-treated soybean meal. Can. J. Anim. Sci. 69:727-734. https://doi.org/10 .4141/cjas89-085.

Montagne, L., I. Crévieu-Gabriel, R. Toullec, and J. P. Lallès. 2003. Influence of dietary protein level and source on the course of protein digestion along the small intestine of the veal calf. J. Dairy Sci. 86:934-943. https://doi.org/10.3168/jds.S0022-0302(03)73676 -5 .

Montagne, L., R. Toullec, M. Formal, and J. P. Lallès. 2000. Influence of dietary protein level and origin on the flow of mucin along the small intestine of the preruminant calf. J. Dairy Sci. 83:2820-2828. https://doi.org/10.3168/jds.S0022-0302(00)75181-2.

Montagne, L., R. Toullec, and J. P. Lallès. 2001. Intestinal digestion of dietary and endogenous proteins along the small intestine of calves fed soybean or potato. J. Anim. Sci. 79:2719-2730. https:// doi.org/10.2527/2001.79102719x.

Morrill, J. L., S. L. Melton, A. D. Dayton, E. J. Guy, and M. J. Pallansch. 1971. Evaluation of milk replacers containing a soy protein concentrate and high whey. J. Dairy Sci. 54:1060-1063. https://doi .org/10.3168/jds.S0022-0302(71)85970-2.

Nitsan, Z., R. Volcani, A. Hasdai, and S. Gordin. 1972. Soybean protein substitute for milk protein in milk replacers for suckling calves. J. Dairy Sci. 55:811-821. https://doi.org/10.3168/jds S0022-0302(72)85576-0.

O'Dell, B. L. 1979. Effect of soy protein on trace mineral availability. Pages 187-207 in Soy Protein and Human Nutrition. Academic Press, St. Louis, MO.

Raeth, M., H. Chester-Jones, D. Ziegler, B. Ziegler, D. Schimek, D. L. Cook, G. Golombeski, and A. V. Grove. 2016. Pre- and postweaning performance and health of dairy calves fed milk replacers with differing protein sources. Prof. Anim. Sci. 32:833-841. https://doi .org/10.15232/pas.2016-01536.

Rauba, J., B. J. J. Heins, H. Chester-Jones, H. L. L. Diaz, D. Ziegler, J. Linn, and N. Broadwater. 2019. Relationships between protein and energy consumed from milk replacer and starter and calf growth and first-lactation production of Holstein dairy cows. J. Dairy Sci. 102:301-310. https://doi.org/10.3168/jds.2018-15074.

Rey, M., F. Enjalbert, and V. Monteils. 2012. Establishment of ruminal enzyme activities and fermentation capacity in dairy calves from birth through weaning. J. Dairy Sci. 95:1500-1512. https:// doi.org/10.3168/jds.2011-4902.

Sedgman, C. A., J. H. B. Roy, J. Thomas, I. J. F. Stobo, and P. Ganderton. 1985. Digestion, absorption and utilization of single-cell protein by the preruminant calf. Br. J. Nutr. 54:219-244. https:// doi.org/10.1079/BJN19850107.

Senevirathne, N. D., J. L. Anderson, W. R. Gibbons, and J. A. Clapper. 2017. Growth performance of calves fed microbially enhanced soy protein in pelleted starters. J. Dairy Sci. 100:199-212. https:/ /doi.org/10.3168/jds.2016-11221. 
Shoptaw, L. 1936. Soybean flour as a substitute for cow's milk in feeding dairy calves. J. Dairy Sci. 19:95-99. https://doi.org/10.3168/ jds.S0022-0302(36)93041-2.

Singh, P., R. Kumar, S. N. Sabapathy, and A. S. Bawa. 2008. Functional and edible uses of soy protein products. Compr. Rev. Food Sci. Food Saf. 7:14-28. https://doi.org/10.1111/j.1541-4337.2007 $.00025 . x$.

Sissons, J. W. 1982. Effects of soya-bean products on digestive processes in the gastrointestinal tract of preruminant calves. Proc. Nutr. Soc. 41:53-61. https://doi.org/10.1079/PNS19820007.

Smith, R. H., and J. W. Sissons. 1975. The effect of different feeds, including those containing soya-bean products, on the passage of digesta from the abomasum of the preruminant calf. Br. J. Nutr. 33:329-349. https://doi.org/10.1079/BJN19750039.

Stein, H. H., B. Sève, M. F. Fuller, P. J. Moughan, and C. F. M. De Lange. 2007. Invited review: Amino acid bioavailability and digestibility in pig feed ingredients: Terminology and application. J. Anim. Sci. 85:172-180. https://doi.org/10.2527/jas.2005-742.

Sun, P., J. Q. Wang, and H. T. Zhang. 2010. Effects of Bacillus subtilis natto on performance and immune function of preweaning calves. J. Dairy Sci. 93:5851-5855. https://doi.org/10.3168/jds.2010-3263.

Tukur, H. M., J. P. Lallès, C. Mathis, I. Caugant, and R. Toullec. 1993. Digestion of soybean globulins, glycinin, $\alpha$-conglycinin and $\beta$-conglycinin in the preruminant and the ruminant calf. Can. J. Anim. Sci. 73:891-905. https://doi.org/10.4141/cjas93-091.

Waller, S. L. 1973. Prostaglandins and the gastrointestinal tract. Gut 14:402-417. https://doi.org/10.1136/gut.14.5.402.

Wang, H. L., E. W. Swain, L. L. Wallen, and C. W. Hesseltine. 1975. Free fatty acids identified as antitryptic factor in soybeans fermented by Rhizopus oligosporus. J. Nutr. 105:1351-1355. https:// doi.org/10.1093/jn/105.10.1351.

Wolfswinkel, T. L. 2009. The effects of feeding fermented soybean meal in calf starter on growth and performance of dairy calves. Graduate Theses and Dissertations. 11061. MS, Animal Science, Iowa State University.

ZeidAli-Nejad, A., G. R. Ghorbani, S. Kargar, A. Sadeghi-Sefidmazgi, A. Pezeshki, and M. H. Ghaffari. 2018. Nutrient intake, rumen fermentation and growth performance of dairy calves fed extruded full-fat soybean as a replacement for soybean meal. Animal 12:733-740. https://doi.org/10.1017/S1751731117002154.

\section{ORCIDS}

I. Ansia (ำ https://orcid.org/0000-0002-9114-4178

J. K. Drackley (ํ) https://orcid.org/0000-0002-4560-5594 